Алекса М. Поповић ${ }^{1}$

Универзитет у Нишу

Филозофски факултет
UDK 271.2:929 Ненадовић П.“"17“"

DOI: https://doi.org/10.46630/gsoc.25.2020.06

\title{
НАЈУТИЦАЈНИЈА ФИГУРА СРПСКОГ НАРОДА У ПЕРИОДУ 1749-1768 ГОДИНЕ
}

(Ненад Нинковић, Митрополит Павле Ненадовић, Филозофски факултет у Новом Саду, Историјски архив „Срем“, Нови Сад - Сремска Митровица, 2017, 539 страна)

Личност и делатност Павла Ненадовића, поглавара Карловачке митрополије у периоду 1749-1768 године, представља изазовну тему за историографско истраживање и поставља сложен задатак пред истраживача. Монографија Митрополит Павле Ненадовић, аутора Ненада Нинковића, доцента на Одсеку за историју Филозофског факултета Универзитета у Новом Саду, у издању Филозофског факултета Универзитета у Новом Саду и Историјског архива „Срем“ у Сремској Митровици, представља, у досадашњој историографији, најпотпунију биографију Павла Ненадовића. Монографија која је пред читаоцима, уређена је по тематско-хронолошком принципу. Личност Павла Ненадовића је смештена у контекст положаја српског народа у Хабзбуршкој Монархији и спољних и унутрашњих друштвенополитичких прилика Хабзбуршке Монархије.

Монографија представља приређену и допуњену докторску дисертацију Ненада Нинковића, под називом Политичка и културна делатност митрополита Павла Ненадовића, одбрањену 7. маја 2015. године на Филозофском факултету у Новом Саду. Заснована је, понајвише, на архивској грађи, из фондова Архива Српске академије наука и уметности у Сремским Карловцима (Митрополијско-патријаршијски архив), Архива Српске академије наука и уметности у Београду, Архива Србије у Београду, Архива Епархије будимске у Сентандреји, Архива Војводине у Новом Саду, Државног архива Аустрије (Ратни архив) у Бечу (Österreichisches Staatsarchiv, Kriegsarchiv, Wien) и Рукописног одељења Матице српске у Новом Саду, али су, такође, током израде монографије прегледани и критички проучени и релевантна литература и објављени извори везани за истраживану тему.

Књига је подељена на шест поглавља: На путу ка митрополијском трону (17-78); Више од архиепископа, мање од сариt nationis-a (79-170); Колико воле неуните верне (171-254); Еванђелска кротост крутог аутократе (255-370); Организачија и реорганизаџија у Архидијецези (371-426); Да народ умно прог-

\footnotetext{
${ }^{1}$ aleksa.popovic@filfak.ni.ac.rs
} 
леда преко својих синова (427-489); са Предговором (7) и Уводом (11-16) испред и Закључком, на српском, енглеском и немачком језику (490-497, Conclusion 498-505, Schlussfolgerung 506-514); прилозима под насловом Портрети Павла Ненадовића (516-520) и одељком Извори и литература (521-536), после основног текста. Свако поглавље, подељено је у неколико потпоглавља, у којима су истражени појединачни аспекти живота и рада Павла (Ненадовића).

У првом поглављу, описан је живот Петра (у монаштву - Павла) Ненадовића до доласка на митрополијски трон. Пружен је увид у његово порекло, егзархијску и епископску службу и околности избора за митрополита. Друго поглавље је посвећено Павловој делатности на одбрани привилегија, позитивним и негативним утицајима на овај аспект митрополитове делатности. Тежиште је стављено на упорну и доследну борбу, како митрополита, тако и епископа и других органа српске црквенонародне аутономије, за одбрану привилегија. У том смислу, митрополит Павле (Ненадовић) је задао и следио једну врло круту, на тренутке и штетну по српске интресе, политику, коју су одређивала три основна начела: да се Привилегије имају тумачити у изворном облику, да се настоји на томе да се сви православни у Хабзбуршкој Монархији ставе под јурисдикцију Карловачке митрополије и да се не дозволи ниједан преседан који би могао довести до сужавања Привилегија, тренутно или у будућности. Треће поглавље обрађује питање унијаћења у Хрватској и Славонији, Арадској епископији и Ердељу. Канонска питања, однос са Пећком патријаршијом и везе са православнима у Хабзбуршкој Монархији, тема су четвртог поглавља. Павле је био изузетно посвећен изградњи црквене организације, угледа и реда унутар црквених структура, што је захтевало изразито ауторитарни, неретко и аутократски приступ, по чему се митрополит Павле истицао. Образовање свештенства и народа имало је велики утицај на касније генерације. Иако се Павлов рад његовом смрћу окончао, темељи које је он поставио, нису могли бити пољуљани. Организација и реорганизација црквене и школске структуре српског становништва у Хабзбуршкој Монархији је тема петог и шестог поглавља, где су сагледане Павлове просветитељске идеје, његов упоран рад на организацији и увођењу строгог реда у унутарцрквени и народни живот (увек у оквирима црквенонародне аутономије схваћене у најширем обиму), оснивању школа и школских фондова, као и последњи дани митрополита Павла (Ненадовића).

Умешно организовање текста, који је разложен на заокружене тематскохронолошке целине, а свака од њих на мање, предметне, целине, у којима су обрађена појединачна питања, као и наслови поглавља и потпоглавља, за које су често узимани цитати из изворне грађе, одају, већ при првом погледу, ауторово владање материјом, што се кроз ишчитавање текста потврђује.

Истраживањем Ненада Нинковића, решена су и поједина хронолошка питања, од којих, свакако, посебно место заслужују године рођења и замонашења Петра Ненадовића. Година рођења Петра (у монаштву Павла) Ненадовића се у ранијој литератури (на основу извора) наводила као 1699. или 1702. Нинковић je, истраживши до сада непознату грађу, утврдио да је Петар Ненадовић рођен 
1701. године. Такође, време Петровог замонашења, Нинковић помера на 1733. годину, када се, децембра те године, под монашким именом Павле, Ненадовић помиње у манастиру Раковац.

На карактер, личност Павлову, али и на његов будући рад, умногоме је утицала средина у којој је рођен и стасао. Потекао је из угледне трговачке породице, рођен и одрастао у најзначајнијем средишту српског народа онога времена - Будиму. У световном животу, бавио се занатом и трговином, али је на његов потоњи рад од пресудне важности било учешће у посланствима Будимаца у Бечу. Као изузетно образован за своје време, помиње се као свештеник, мада без парохије, а убрзо потом и као придворни свештеник на митрополијском двору. Од тренутка замонашења (1733) до тренутка када је преузео Горњокарловачку епархију (1739) није прошло много времена, а још одмах по замонашењу, митрополит Вићентије (Јовановић) настојао је да Павле буде изабран и хиротонисан за владику горњокарловачког.

Колико год деловало парадоксално, српска црква у Хабзбуршкој Монархији је била изузетно динамична, у реформама које су обележиле XVIII век, она је у српском народу предњачила, до краја века често испред трговачког слоја. Положај митрополита био је највиши положај у читавом српском друштву осамнаестога века. Тај положај је омогућавао Павлу да унутар Карловачке митрополије спроведе реорганизацију која је за циљ имала стварање институције која је самостално могла да одбрани интересе српског народа у Монархији. Да би тај циљ био остварен, било је неопходно да се у унутрашњу администрацију Карловачке митрополије уведу ред и строга дисциплна. Реформна делатност митрополита Павла (Ненадовића) била је део терезијанских просветитељских реформи, једнако као што је била наставак оне делатности коју су на реформи, уређењу и напретку Митрополије, као кровне институције српског народа у Хабзбуршкој Монархији и, са њом, читавог народа, изводили Мојсије (Петровић), Вићентије (Јовановић) и Арсеније IV (Јовановић Шакабента).

Оно што је обележило живот Павла (Ненадовића), а што се као црвена нит провлачи кроз читаву монографију, јесте образовање. Наиме, Петар Ненадовић је био један од најобразованијих људи свог времена, без обзира на то колики је у томе био удео формалног, а колики неформалног образовања, искуства и утицаја породице и најближе околине. Рад на народноцрквеним пословима у Бечу, у служби општине будимске или Митрополије, као и рад на месту генералног викара митрополијског, умногоме су припремили Петра (Павла) за каснију службу на месту епископа горњокарловачког и митрополита карловачког. У кратком року, 1748/1749, од укупно осам епархија Карловачке митрополије, упражњено је остало пет (Вршачка, Арадска, Будимска, Горњокарловачка, Костајничка), што је у тренутку избора Павла (Ненадовића) за митрополита, оставило само тројицу владика (бачког Висариона Павловића, темишварског Георгија Поповића и пакрачког Софронија Јовановића). У овом погледу, Павле је поступао на начин који је већ одавао његову ауторитарну природу, али са великим занимањем за положај народа. Постављањем људи од свог великог поверења на места епископа, створио је чврсте основе за даљи 
наставак свог рада на уређењу питања народноцрквене аутономије и распростирање просветитељских идеја на подручју Карловачке митрополије. Друга важна околност која је обележила Павлово време, јесте његова дуговечност и виталност до саิмог краја живота. За деветнаест година Павлових на врху Митрополије, створени су услови за функционисање цркве и њене организације и после његове смрти.

На месту митрополита, Павле (Ненадовић) је уложио велики труд у оснивање школа. Његовим трудом основане су Покровобогородичне школе (Словенска, Латинско-немачка, Клирикална, привремено и Грчка школа) у Карловцима (1749-1769), у рангу гимназије, Клирикални фонд (1749) за издржавање српских основних и виших школа, док је из заоставштине митрополита Павла, на Сабору 1769. године основан Неприкосновени фонд. Још на месту епископа горњокарловачког, Павле је настојао да се отварају основне, варошке и сеоске школе, што је наставио и на месту митрополита, што је наилазило на честе отпоре земаљских власти. На Синоду 1750. године, одлучено је да парохијски свештеници на „недељним школама“ недељом и о празницима вернике имају учити основним молитвама. За пропусте и неиспуњавање дужности у овом погледу, биле су предвиђене казне.

Као најснажнији чинилац у одбрани од уније, одржању у православној вери и општем напретку народа, Павле је видео образовање. Ове погледе, са њим су делили и епископи Карловачке митрополије и други истакнути људи средине XVIII века. Активност на унапређењу школства, заснивала се на ставу усвојеном још у време митрополита Вићентија (Поповића) (1713-1725), да народ може напредовати само кроз образовање. Образовање, такође, чини становништво способним да напредује у економском погледу, што је било и становиште државе. Са друге стране, овиме је ослабљен најснажнији, економски, разлог преласка на унију. Поред начелног става да су образовани појединци ти који представљају најугледнији део народа, који омогућују „да народ умно прогледа преко својих синова“, митрополит Павле је посветио велику пажњу просвећивању свих слојева народа. Поуке и беседе митрополита Павла читане су након литургије (присуство на литургији је било обавезно), те су идеје рационлизма и просветитељства, о значају рада, образовања и духовног уздизања допирале до најширих народних слојева. Пастирским радом Павла (Ненадовића), у чему је имао и подршку и сарадњу владика, нарочито вршачког, Јована (Георгијевића), ојачан је култ националних светитеља.

Иако су главне просветитетљске реформе у Карловачкој митрополији наступиле након смрти Павла (Ненадовића), он је доказао да се без школа и конзисторија (црквених судова) не може одржати снага Митрополије пред наступом (показаће се, последњим великим таласом) унијатске пропаганде, током „покрета рекатолизације“ у време Марије Терезије (1740-1780). Читава генерација српских просветитеља, чак и оних на чији рад није непосредно утицао, попут Захарије Орфелина (1726-1785), Јована Рајића (1726-1801) или Доситеја Обрадовића (1739-1811), проистекли су из резултата просветитељске делатности митрополита Павла (Ненадовића). Поред свих позитивних резул- 
тата, савременици Павла (Ненадовића) су често превиђали његове негативне стране, нарочито сујету и ауторитарност, која је, у појединим случајевима, доносила више штете но користи, као што је, примера ради, обавезна владарска дозвола за сазивање Синода и увођење комесара на синодалне седнице (1760). Након прочитане монографије, показује се да је задатак који је аутор у Уводу поставио, тј. приказивање проблема из времена Павловог на једном месту, уз поштовање историјске методологије, успешно испуњен. 